\title{
Quality characteristics of white cabbage juice stored using thermal processing and addition of chemical additives
}

\section{Gurpreet Kaur* and Poonam Aggarwal}

Department of Food Science and Technology, Punjab Agricultural University, Ludhiana-141004 (Punjab), INDIA *Corresponding author. E-mail: gurpreet.pau.86@gmail.com

Received: July 19, 2016; Revised received: December 9, 2016; Accepted: February 21, 2017

\begin{abstract}
Cabbage (Brassica oleracea L. var. capitata) is one of the most important vegetables grown worldwide. Cabbage is valued for medicinal purposes in treating headaches, gout, diarrhea and peptic ulcers. The beneficial phytochemicals in cabbage help to activate and stabilize the body's antioxidant and detoxification mechanisms that dismantle and eliminate cancer-producing substances. This seasonal vegetable can be made available for the consumers in off seasons also in the form of juice. The juice can be made shelf stable by using thermal treatment and various chemical additives. Therefore, the aim of the experiment was to compare the effect of different chemical additives namely Sodium benzoate, Potassium metabisulfite (KMS) and their combinations and the heat treatment, on the physicochemical, phytochemical parameters and antioxidant activity of Cabbage juice for a period of 6 months at room temperature at the regular intervals. The parameters like TS and TSS did not change significantly. The minimum increase in acidity was found in samples treated with combination of Sodium benzoate and Potassium metabisulfite. The color was best preserved by addition of KMS where the $L$ value changed from 52.66 to 50.86 after 6 months. The ascorbic acid, total phenol content and antioxidant activity was best preserved by KMS with final values of $2.51 \mathrm{mg} / 100 \mathrm{~g}, 21.18 \mathrm{mg} / 100 \mathrm{~g}$ and $15.97 \%$ respectively that were far better than the thermally treated samples with values $1.47 \mathrm{mg} / 100 \mathrm{~g}, 8.14 \mathrm{mg} / 100 \mathrm{~g}$ and $6.98 \%$ respectively. Keeping in view all the parameters KMS was found to be the most appropriate agent for preservation.
\end{abstract}

Keywords: Antioxidant activity, Cabbage, Phytochemicals, Storage

\section{INTRODUCTION}

Cabbage (Brassica oleracea L. var. capitata), ashallow -rooted, cool season crop is one of the most important vegetables grown worldwide. It belongs to the family Cruciferae, which includes Brussels sprouts, broccoli, cauliflower and kale. Cabbage is consumed either raw or processed in different ways, e.g., boiled or, fermented or, used in salads. Fresh cabbage juice, prepared either separately or mixed with other vegetables such as carrot and celery, is often included in many commercial weight-loss diets (Samec et al., 2011). Due to its anti-inflammatory and antibacterial properties, cabbage has widespread use in traditional medicine, in alleviation of symptoms associated with gastrointestinal disorders (gastritis, peptic and duodenal ulcers, irritable bowel syndrome) as well as in treatment of minor cuts and wounds and mastitis, improve the bioavailable content of nonheme iron (Chiplonkar et al., 1999). Cabbage is good detoxifier, which purifies blood and removes toxinsdue to the presence of vitamin C and sulphur (Tang et al., (2007) in good amount. The beneficial phytochemicals in cabbage help activate and stabilize the body's antioxidant and detoxification mechanisms that dismantle and eliminate cancer-producing substances (Brooks et al.,
2001). Epidemiological data as well as in vitro studies strongly suggest that vegetables having antioxidant phytochemicals have strong protective effects against major degenerative diseases including cancer and cardiovascular diseases (Block et al., 1992). The protective action of cruciferous vegetables has been attributed to the presence of antioxidant phytochemicals, (Prior and Cao, 2000). Interest in the role of free radical scavenging-antioxidants in human health has prompted research in the fields of horticulture and food science to assess the antioxidant phytochemicals in fruits and vegetables. During the harvesting season, large quantities get spoiled due to excess production. So a Long term preservation method is required that could be useful to prevent spoilage of cabbage such that it could be consumed in off seasons as well. For such reasons, cabbage can be processed into a shelf stable juice. Some studies have been conducted to quantify the physicochemical, phytochemical and antioxidant activity of cabbage and members of this family, so far, there has not been a systematic study on the effect of chemical additives or preservatives on the shelf life of processed cabbage juice. Keeping in view, the present study was conducted to process and preserve the cabbage juice acceptable of a longer period of time. 


\section{MATERIALS AND METHODS}

Raw materials: The study was conducted in the Department of Food Science and Technology, Punjab Agricultural University, Ludhiana. Cabbage was procured from the Department of Vegetable Science, Punjab Agricultural University, Ludhiana.

Extraction process of cabbage juice: Fresh cabbages were washed thoroughly and cut off from the top and were not peeled. The Cabbage juice was extracted in a juicer extractor (Kalsi: 9001-2008). The juice was pasteurized at $83{ }^{\circ} \mathrm{C}$ for $3 \mathrm{~min}$ and citric acid @ $0.15 \%$ was added, followed by chemical preservatives.

Dose distribution of chemical additives:

\begin{tabular}{lll}
\hline Sample & Chemical additives & Dose (ppm) \\
\hline $\mathrm{T}_{2}$ & Na-benzoate & 3000 \\
$\mathrm{~T}_{3}$ & KMS & 3000 \\
$\mathrm{~T}_{4}$ & Na-benzoate + KMS & $1500+1500$ \\
\hline
\end{tabular}

The pre-sterilized glass bottles were filled with the hot juice and corked. $\mathrm{T}_{1}$ sample was given the pasteurization treatment followed by processing at $100{ }^{\circ} \mathrm{C}$ for 20 min in boiling water bath and gradually cooled to a low temperature under running tap water. These processed juices were kept for storage at room temperature for six months.

Physico-chemical analysis: Cabbage juices were analysed at regular interval of one month for the parameters like Total solids, Titratable acidity using AOAC (2000) methods. TSS was taken using hand refractometer (ERMA, Japan), color using Minolta Hunter colorimeter.
Phytochemical analysis: For phytochemical parameters, Vitamin $\mathrm{C}$ was determined by the titrimetric method using dichlorophenol indophenol dye (Ranganna, 1986). Total phenolic content was determined by Folin-ciocalteau reagent (Singleton and Rossi, 1965). A standard curve was plotted by taking known amount of Gallic acid as reference standard and concentration was calculated from the standard curve. The \% Antioxidant activity was determined by DPPH (2, 2-diphenyl-2-picrylhydrazyl) method (BrandWilliams et al., 1995). Methanolic extract of sample was taken for antioxidant activity analysis and calculated according to the following formula. BHT was taken as a standard at a fixed concentration of 5 $\mathrm{mg} / \mathrm{ml}$.

$\% \mathrm{AA}=\frac{\text { Control OD(0 min })- \text { Sample OD(30 min })}{\text { Control OD }(0 \mathrm{~min})} \times 100$

The samples were studied for the effect of different chemical additives on physicochemical [TS, TSS, acidity, color (L, a, b)], phytochemical (ascorbic acid, total phenols) and $\%$ antioxidant activity for the storage period of 6 months.

Statistical analysis: The results were evaluated by Analysis of Variance (ANOVA) and Tukey's post hoc tests using Systat statistical program version 16 (SPSS Inc., USA).

\section{RESULTS AND DISCUSSION}

Effect on total solids and TSS: TS increased nonsignificantly $(\mathrm{p} \leq 0.05)$ in all the juices of cabbage dur-

Table 1. Effect of storage period and treatments on titratable acidity (\%) of cabbage juice.

\begin{tabular}{lccccccc}
\hline \multirow{2}{*}{ Treatments } & \multicolumn{7}{c}{ Storage months } \\
\cline { 2 - 8 } & 0 & 1 & 2 & 3 & 4 & 5 & 6 \\
\hline $\mathrm{T} 1$ & $0.341^{\mathrm{aB}}$ & $0.378^{\mathrm{aB}}$ & $0.401^{\mathrm{aB}}$ & $0.425^{\mathrm{aC}}$ & $0.467^{\mathrm{aB}}$ & $0.504^{\mathrm{aB}}$ & $0.584^{\mathrm{aBC}}$ \\
$\mathrm{T} 2$ & $0.373^{\mathrm{aA}}$ & $0.405^{\mathrm{aA}}$ & $0.439^{\mathrm{aA}}$ & $0.483^{\mathrm{aA}}$ & $0.519^{\mathrm{aA}}$ & $0.551^{\mathrm{aA}}$ & $0.586^{\mathrm{aA}}$ \\
$\mathrm{T} 3$ & $0.373^{\mathrm{aA}}$ & $0.392^{\mathrm{aAB}}$ & $0.423^{\mathrm{aAB}}$ & $0.456^{\mathrm{aB}}$ & $0.481^{\mathrm{aB}}$ & $0.506^{\mathrm{aB}}$ & $0.549^{\mathrm{aB}}$ \\
$\mathrm{T} 4$ & $0.373^{\mathrm{aA}}$ & $0.392^{\mathrm{aAB}}$ & $0.415^{\mathrm{aAB}}$ & $0.442^{\mathrm{aBC}}$ & $0.475^{\mathrm{aAB}}$ & $0.496^{\mathrm{aB}}$ & $0.516^{\mathrm{aC}}$ \\
\hline
\end{tabular}

* Data is expressed as means of 3 readings and values followed by different upper case or lower case letters are significantly different $(\mathrm{p} \leq 0.05)$ within columns and rows respectively.

Table 2. Effect of storage period and treatments on the color values ( $\mathrm{L}$ a b) of cabbage juice.

\begin{tabular}{|c|c|c|c|c|c|c|c|c|}
\hline \multirow{2}{*}{\multicolumn{2}{|c|}{ Treatments }} & \multicolumn{7}{|c|}{ Storage months } \\
\hline & & 0 & 1 & 2 & 3 & 4 & 5 & 6 \\
\hline \multirow{4}{*}{$\mathbf{L}$} & $\mathrm{T} 1$ & $44.67^{\mathrm{aC}}$ & $44.12^{\mathrm{aC}}$ & $43.77^{\mathrm{abC}}$ & $43.16^{\mathrm{abD}}$ & $42.43^{\mathrm{abcD}}$ & $41.64^{\mathrm{bcD}}$ & $40.55^{\mathrm{cD}}$ \\
\hline & $\mathrm{T} 2$ & $47.83^{\mathrm{aB}}$ & $47.19^{\mathrm{abB}}$ & $46.54^{\mathrm{abcB}}$ & $46.02^{\mathrm{abcC}}$ & $45.67^{\mathrm{abcC}}$ & $44.92^{\mathrm{bcC}}$ & $44.12^{\mathrm{cC}}$ \\
\hline & $\mathrm{T} 3$ & $52.66^{\mathrm{aA}}$ & $52.39^{\mathrm{aA}}$ & $52.07^{\mathrm{aA}}$ & $51.83^{\mathrm{aA}}$ & $51.52^{\mathrm{aA}}$ & $51.28^{\mathrm{aA}}$ & $50.86^{\mathrm{aA}}$ \\
\hline & $\mathrm{T} 4$ & $50.71^{\mathrm{aA}}$ & $50.32^{\mathrm{aA}}$ & $49.96^{\mathrm{abA}}$ & $49.47^{\mathrm{abB}}$ & $48.87^{\mathrm{abB}}$ & $48.27^{\mathrm{abB}}$ & $47.57^{\mathrm{bB}}$ \\
\hline \multirow{4}{*}{$\mathbf{A}$} & $\mathrm{T} 1$ & $0.28^{\mathrm{dA}}$ & $0.32^{\mathrm{cdA}}$ & $0.39^{\mathrm{bcdA}}$ & $0.46^{\mathrm{abcdA}}$ & $0.51^{\mathrm{abcA}}$ & $0.57^{\mathrm{abA}}$ & $0.63^{\mathrm{aA}}$ \\
\hline & $\mathrm{T} 2$ & $0.33^{\mathrm{bAB}}$ & $0.35^{\mathrm{bAB}}$ & $0.38^{\mathrm{abA}}$ & $0.42^{\mathrm{abA}}$ & $0.47^{\mathrm{abA}}$ & $0.51^{\mathrm{abA}}$ & $0.58^{\mathrm{aA}}$ \\
\hline & $\mathrm{T} 3$ & $0.23^{\mathrm{cAB}}$ & $0.26^{\mathrm{bcAB}}$ & $0.3^{\mathrm{bcAB}}$ & $0.35^{\mathrm{abcAB}}$ & $0.42^{\mathrm{abcA}}$ & $0.48^{\mathrm{abA}}$ & $0.55^{\mathrm{aA}}$ \\
\hline & $\mathrm{T} 4$ & $0.12^{\mathrm{aB}}$ & $0.13^{\mathrm{aB}}$ & $0.15^{\mathrm{aA}}$ & $0.18^{\mathrm{aB}}$ & $0.21^{\mathrm{aB}}$ & $0.25^{\mathrm{abB}}$ & $0.29^{\mathrm{aB}}$ \\
\hline \multirow{4}{*}{ B } & $\mathrm{T} 1$ & $-0.02^{\mathrm{aB}}$ & $-0.04^{\mathrm{abB}}$ & $-0.08^{a b B}$ & $-0.12^{a b B}$ & $-0.16^{a b B}$ & $-0.21^{\mathrm{abB}}$ & $-0.25^{b B}$ \\
\hline & $\mathrm{T} 2$ & $0.19^{\mathrm{aA}}$ & $0.17^{\mathrm{aA}}$ & $0.15^{\mathrm{aA}}$ & $0.12^{\mathrm{aA}}$ & $0.09^{\mathrm{aA}}$ & $0.06^{\mathrm{aA}}$ & $0.02^{\mathrm{aA}}$ \\
\hline & $\mathrm{T} 3$ & $0.03^{\mathrm{aAB}}$ & $0.02^{\mathrm{aAB}}$ & $0.01^{\mathrm{aAB}}$ & $-0.02^{\mathrm{aAB}}$ & $-0.04^{\mathrm{aAB}}$ & $-0.07^{\mathrm{aAB}}$ & $-0.1^{\mathrm{aAB}}$ \\
\hline & $\mathrm{T} 4$ & $0.11^{\mathrm{aAB}}$ & $0.1^{\mathrm{aAB}}$ & $0.08^{\mathrm{aAB}}$ & $0.05^{\mathrm{aAB}}$ & $0.02^{\mathrm{aAB}}$ & $-0.01^{\mathrm{aAB}}$ & $-0.03^{\mathrm{aAB}}$ \\
\hline
\end{tabular}

* Data is expressed as means of 3 readings and values followed by different upper case or lower case letters are significantly different $(\mathrm{p} \leq 0.05)$ within columns and rows respectively. 
Gurpreet Kaur and Poonam Aggarwal / J. Appl. \& Nat. Sci. 9 (1): 568 - 572 (2017)

Table 3. Effect of storage period and treatments on ascorbic acid content $(\mathrm{mg} / 100 \mathrm{~g})$ of cabbage juice.

\begin{tabular}{lccccccc}
\hline \multirow{2}{*}{ Treatments } & \multicolumn{7}{c}{ Storage months } \\
\cline { 2 - 7 } & 0 & 1 & 2 & 3 & 4 & 5 & 6 \\
\hline T1 & $6.98^{\mathrm{aA}}$ & $6.43^{\mathrm{aA}}$ & $5.46^{\mathrm{abA}}$ & $4.21^{\mathrm{bcA}}$ & $3.95^{\mathrm{bcA}}$ & $2.69^{\mathrm{cdA}}$ & $1.47^{\mathrm{dA}}$ \\
T2 & $7.75^{\mathrm{aA}}$ & $7.52^{\mathrm{aA}}$ & $6.29^{\mathrm{abA}}$ & $5.11^{\mathrm{bcA}}$ & $4.89^{\mathrm{bcA}}$ & $3.62^{\mathrm{cdA}}$ & $2.38^{\mathrm{eA}}$ \\
T3 & $7.75^{\mathrm{aA}}$ & $7.56^{\mathrm{abA}}$ & $6.68^{\mathrm{abcA}}$ & $5.57^{\mathrm{bcdA}}$ & $4.86^{\mathrm{cdA}}$ & $3.75^{\mathrm{deA}}$ & $2.51^{\mathrm{eA}}$ \\
T4 & $7.75^{\mathrm{aA}}$ & $7.59^{\mathrm{aA}}$ & $6.61^{\mathrm{abA}}$ & $5.72^{\mathrm{abcA}}$ & $4.63^{\mathrm{bcdA}}$ & $3.86^{\mathrm{cdA}}$ & $2.49^{\mathrm{dA}}$ \\
\hline
\end{tabular}

* Data is expressed as means of 3 readings and values followed by different upper case or lower case letters are significantly different $(\mathrm{p} \leq 0.05)$ within columns and rows respectively.

Table 4. Effect of storage period and treatments on total phenols $(\mathrm{mg} / 100 \mathrm{~g})$ of cabbage juice.

\begin{tabular}{lccccccc}
\hline \multirow{2}{*}{ Treatments } & \multicolumn{7}{c}{ Storage months } \\
\cline { 2 - 8 } & 0 & 1 & 2 & 3 & 4 & 5 & 6 \\
\hline $\mathrm{T} 1$ & $25.41^{\mathrm{aA}}$ & $23.85^{\mathrm{aA}}$ & $21.64^{\mathrm{abA}}$ & $18.14^{\mathrm{abA}}$ & $15.76^{\mathrm{abA}}$ & $12.62^{\mathrm{abA}}$ & $8.14^{\mathrm{bA}}$ \\
$\mathrm{T} 2$ & $34.76^{\mathrm{aA}}$ & $32.17^{\mathrm{aA}}$ & $29.61^{\mathrm{abA}}$ & $26.29^{\mathrm{abA}}$ & $23.82^{\mathrm{abA}}$ & $20.96^{\mathrm{abA}}$ & $16.79^{\mathrm{bA}}$ \\
$\mathrm{T} 3$ & $35.11^{\mathrm{aA}}$ & $33.79^{\mathrm{aA}}$ & $31.17^{\mathrm{abA}}$ & $29.62^{\mathrm{abA}}$ & $27.19^{\mathrm{abA}}$ & $24.76^{\mathrm{abA}}$ & $21.18^{\mathrm{bA}}$ \\
$\mathrm{T} 4$ & $35.72^{\mathrm{aA}}$ & $33.88^{\mathrm{aA}}$ & $31.79^{\mathrm{abA}}$ & $28.96^{\mathrm{abA}}$ & $26.64^{\mathrm{abA}}$ & $23.85^{\mathrm{abA}}$ & $19.27^{\mathrm{bA}}$ \\
\hline
\end{tabular}

* Data is expressed as means of 3 readings and values followed by different upper case or lower case letters are significantly different $(\mathrm{p} \leq 0.05)$ within columns and rows respectively.

Table 5. Effect of storage period and treatments on $\%$ antioxidant activity of cabbage juice.

\begin{tabular}{lccccccc}
\hline \multirow{2}{*}{ Treatments } & \multicolumn{7}{c}{ Storage months } \\
\cline { 2 - 8 } & 0 & 1 & 2 & 3 & 4 & 5 & 6 \\
\hline T1 & $22.81^{\mathrm{aB}}$ & $20.37^{\mathrm{abB}}$ & $18.87^{\mathrm{abB}}$ & $15.49^{\mathrm{bcB}}$ & $12.08^{\mathrm{cdB}}$ & $9.76^{\mathrm{deB}}$ & $6.98^{\mathrm{eB}}$ \\
T2 & $27.63^{\mathrm{aA}}$ & $25.59^{\mathrm{abA}}$ & $23.96^{\mathrm{abcA}}$ & $21.52^{\mathrm{bcdA}}$ & $19.21^{\mathrm{cdA}}$ & $16.87^{\mathrm{deA}}$ & $13.26^{\mathrm{eA}}$ \\
T3 & $28.55^{\mathrm{aA}}$ & $26.02^{\mathrm{abA}}$ & $24.59^{\mathrm{abcA}}$ & $22.17^{\mathrm{bcdA}}$ & $20.85^{\mathrm{cdeA}}$ & $18.49^{\mathrm{deA}}$ & $15.97^{\mathrm{eA}}$ \\
T4 & $28.08^{\mathrm{aA}}$ & $26.16^{\mathrm{abA}}$ & $24.71^{\mathrm{abcA}}$ & $22.46^{\mathrm{bcdA}}$ & $20.12^{\mathrm{cdA}}$ & $17.73^{\mathrm{deA}}$ & $14.24^{\mathrm{eA}}$ \\
\hline
\end{tabular}

* Data is expressed as means of 3 readings and values followed by different upper case or lower case letters are significantly different $(\mathrm{p} \leq 0.05)$ within columns and rows respectively.

ing the storage. On the day of preparation, the amount $\%$ of TS in sample T1, T2, T3, T4 were 14.28, 13.66, 14.45 and 14.87 respectively. At the end of 6 months, the TS in the samples increased to $16.44,14.88,15.51$ and 15.81 respectively. The $\%$ TSS values of samples $\mathrm{T}_{1}$ to $\mathrm{T}_{4}$ on day first was 7.4 for each sample which gradually increased to $7.7,7.6,7.5$ and 7.5 respectively after 6 months of storage. Although TSS increased for all the samples but the changes were non-significant $(\mathrm{p} \leq 0.05)$. An increase in soluble content of apple pulp was reported during storage when preserved with chemical preservatives. Preservatives like sodium benzoate, potassium metabisulphite and citric acid in various combinations (Durrani et al., 2010). The treatments had no significant effect $(\mathrm{p} \leq 0.05)$ on total solids as well as TSS.

Effect on acidity: The chemical additives as well as storage had no significant effect $(\mathrm{p} \leq 0.05)$ on acidity of the cabbage juice. The titratable \% acidity of sample $\mathrm{T}_{1}$ on day first was found to be 0.341 and 0.373 for the three chemically treated samples $\left(T_{1}\right.$ to $\left.T_{3}\right)$ that gradually increased to $0.584,0.586,0.549$ and 0.516 respectively (Table 1). The similar pattern in increase in titratable acidity was found during storageof Jamun RTS beverages for a period of 3 months (Kesharwani et al., 2015). Also, in another study, the percentage of titrable acidity significantly increased from the day of prepara- tion $(0.276 \%)$ to 90 days of storage $(0.299 \%)$ in a study for preparation of blended beverages by utilizing jamun juice (Priyanka et al., 2015).In present study, the acidity of the thermally treated sample $\left(\mathrm{T}_{1}\right)$ increased more as compared to other chemically treated samples and the change was least in $\mathrm{T}_{4}$ sample.

Effect on color ( $L$ a b values): Color is one of the most important visual attributes for juices. The values for color varied significantly $(p \leq 0.05)$, both for storage as well as chemical treatments. On the day of preparation, the lightest sample was $T_{3}$ followed by $T_{4}, T_{2}$ and $\mathrm{T}_{1}$. At the end of 6 months, $\mathrm{T}_{3}$ remained the lightest and $T_{2}$ was found dull than the other samples. The ' $a$ ' value decreased significantly $(\mathrm{p} \leq 0.05)$, but in terms of greenness, $\mathrm{T}_{4}$ was found to be the greenest and retained the maximum greenness than the other 3 samples at the end of 6 months (Table 2). These results corroborated with that of Deka et al., (2005), who found the decrease in hunter color values ' $L$ ' and ' $a$ ' over a storage period of 6 months. The $b$ values were highest for $T_{2}$ and lowest for $T_{1}$ and results after 6 months of storage, remained the same for all the samples. On the whole, sample $\mathrm{T}_{2}$ with Sodium benzoate retained the best color of all the 4 samples. Tomato juice with $\mathrm{Na}$ benzoate seems to be more stable than the other preservatives during 6 months of storage and developed lesser off color and turbidity (Hossain et al., 2011). 
Effect on vitamin $C$ content: Vitamin $C$ is light and heat sensitive, the concentration of Vitamin $\mathrm{C}$ follows first order kinetics and thus storage time affects Vitamin C content (Heldman and Singh, 1981). According to the results, chemical additives have significant effect $(\mathrm{p} \leq 0.05)$ on Vitamin $\mathrm{C}$ content of cabbage juice. Also the Vitamin $\mathrm{C}$ content decreased significantly $(\mathrm{p} \leq 0.05)$ during the storage. On the day of preparation, Vitamin $\mathrm{C}$ content in samples $\mathrm{T}_{1}, \mathrm{~T}_{2}, \mathrm{~T}_{3}$ and $\mathrm{T}_{4}$ was $6.98,7.75,7.75$ and $7.75 \mathrm{mg} / 100 \mathrm{~g}$ respectively. The values came out to be lower in $T_{1}$ as heat treatment destroys Vitamin $C$. This difference in reduction rate of ascorbic acid, a heat sensitive vitamin, may be due to longer exposure time of juice blends to high temperatures (Calskantur et al., 2011). At the end of 6 months, the Vitamin C content reduced to $1.47,2.38$, 2.51 and $2.49 \mathrm{mg} / 100 \mathrm{~g}$ respectively (Table 3 ). Out of the chemically treated samples, potassium metabisulphite

retained the maximum Vitamin $\mathrm{C}$. The application of KMS reduces the loss of ascorbic acid during the storage of leafy vegetables (Negi and Roy, 2000). Also, in a study conducted by Bal et al., (2014), ascorbic acid of guava nectar decreased significantly during the entire storage period of nine months. This reduction might be due to oxidation of ascorbic acid into dehydroascorbic acid by oxygen. These losses of ascorbic acid were attributed to the effect of processing, storage time and exposure to light.

Effect on total phenols: The total phenolic content in samples $T_{1}$ to $T_{4}$ on the first day was $25.41,34.76$, 35.11 and $35.72 \mathrm{mg} / 100 \mathrm{~g}$ respectively. The added chemicals preserved the phenolic content more than thermally treated sample $\left(T_{1}\right)$. But both the treatments and storage affected the total phenols non-significantly $(p \leq 0.05)$. At the end of 6 months, the Total phenolic content came out to be $8.14,16.79,21.18$ and 19.27 $\mathrm{mg} / 100 \mathrm{~g}$ respectively (Table 4 ). According to the findings, a decrease in total polyphenol content of tomato juices after 3, 6 and 9 months of storage were reported (Vallverdu-Queralt et al. 2011). Mgaya-Kilima et al., (2014) concluded a decrease in total phenolic compounds of roselle fruit juice blends stored at $28{ }^{\circ} \mathrm{C}$ for 6 months. The decrease in polyphenols could mainly be resulted from oxidation of these compounds and polymerization with proteins (Liu et al., 2014). The decrease was found to be least in sample $T_{3}$, followed by $\mathrm{T}_{4}$ and $\mathrm{T}_{2}$.

Effect on antioxidant activity: Antioxidants delay the oxidation process, inhibiting the polymerization chain initiated by free radicals and other subsequent oxidizing reactions (Halliwell and Aruoma, 1991). According to the results, on the day of preparation, percent Antioxidant activity for samples $T_{1}$ to $T_{4}$ was found to be $22.81,27.63,28.55,28.08 \mathrm{mg} / 100 \mathrm{~g}$ respectively (Table 5). Significant $(\mathrm{p} \leq 0.05)$ decrease in antioxidant activity was found in treatments and also during stor- age months. At the end of 6 months, the percent antioxidant activity decreased to $6.98,13.26,15.97$ and 14.24 percent respectively. However, the decrease was found to be least in sample $\mathrm{T}_{3}$. It has been reported that the decrease in antioxidant activity may be linked to a decrease in total phenolic content and vitamin $\mathrm{C}$ during storage (Klimczak et al., 2007). According to them, antioxidant activity of orange juices decreased by 45 percent after 6 months of storage at $28^{\circ} \mathrm{C}$. The results of the current investigation are in line with Saci et al., (2015) where the antioxidant activity of carrot and mango beverages decreased significantly after 90 days storage at ambient temperatures. However, in case of cabbage, the vitamin content is relatively high. So the reduction of antioxidant activity is mainly associated with significant decrease in vitamin content.

\section{Conclusion}

It was concluded that potassium metabisulphite proved to be a better preservative than Na-benzoate and their combination for the stability of physicochemical and phytochemical parameters and maintaining the antioxidant activity of the cabbage juice.

In present study, the results for the investigation to find the best treatment for preservation of cabbage juice showed that there were insignificant changes in TS and TSS during the storage. The minimum increase in $\mathrm{pH}$ was found in the sample treated with both sodium benzoate and Potassium metabisulphite where the value increased from $0.373 \%$ to $0.516 \%$ on storage of 6 months. For the parameters like color (L), ascorbic acid, total phenols and \% antioxidant activity, potassium metabisulphite proved to be a better preservative than Na-benzoate and their combination as well as the thermal treatments with the final values of 50.86, 2.51 $\mathrm{mg} / 100 \mathrm{~g}, 21.18 \mathrm{mg} / 100 \mathrm{~g}$ and $15.97 \%$ respectively. Hence, this method of preservation can provide opportunity to farmers facing glut for their crop in the market during season thus reducing the post harvest losses and significantly contributing to the food industry.

\section{REFERENCES}

AOAC (2000). Official Methods of Analysis, 17th ed. Association of official Analytical Chemists, Washington. DC.

Bal, L. M., Ahmad, T., Senapati, A. K . and Pandit, P. S. (2014). Evaluation of quality attributes during storage of guava nectar cv. lalit from different pulp and TSS ratio. J. Food Process. Technol., 5: 329. doi:10.4172/2157-7110.1000329

Block, G., Patterson, B. and Subar, A. (1992). Fruits vegetables and cancer prevention: a review of the epidemiological evidence. Nutr. Cancer, 18 (1): 1-29

Brand-Williams W., Cuvelier, M. E. and Berset, C. (1995). Use of a free radical method to evaluate antioxidant activity. LWT-Food Sci. Technol., 28(1): 25-30

Brooks, J. D., Paton, V. G. and Vidanes, G. (2001). Potent induction of phase 2 enzymes in human prostate cells 
by sulforaphane. Cancer Epidemiol. Biomarkers Prev., 10 (9): 949-954

Calskantur, K. S., Soylemez, Z. and Ozdemir, Y. (2011). Effect of time and temperature on orange juice during storage. Adv Food Sci., 33: 22-27

Chiplonkar S. A., Tarwadi K. V. and Kavedia R. B. (1999). Fortication of vegetarian diets for increasing bioavailable iron density using green leafy vegetables. Food Res Int., 32(3): 169-74

Deka, B. C., Sethi, V. and Ananta, S., (2005). Changes in quality of mango-pineapple spiced beverage during storage. Ind. J Hort., 62(1): 71-75

Durrani, Y. M., Muhammad, A. A. and Ali, A. (2010). Physicochemical response of apple pulp to chemical preservatives and antioxidant during storage. Internet J. Food Saf., 12: 20-28

Halliwell, B. and Aruoma, O. I. (1991). DNA damage by oxygen derived species: its mechanism and measurement in mammalian systems. FEBS Lett.,281(1-2):9-19

health-promoting substances and antioxidant activity of two commercial fruit based-beverages. Int. J. Bioinfor. Biomed. Engg., 1(2): 118-122

Heldman, D. R. and Singh, R. P. (1981). Food Process Engineering. AVI Publishing Co., New York.

Hossain, M. N., Fakruddin, M. and Islam, M. N. (2011). Effect of Chemical additives on the shelf life of Tomato juice. Amer. J. Food Technol., 6: 914-923

Kesharwani, A., Dikshit, S. N., Kumar, K., Thakur, P. and Chandel, N. (2015). Studies on physico-chemical composition of jamun and changes in chemical composition of RTS beverage during storage. The Ecoscan, 7: 379383

Klimczak, I., Matecka, M., Szlachta, M. and GliszczynskaSwiglo, A. (2007). Effect of storage on the content of polyphenols, Vitamin $\mathrm{C}$ and the antioxidant activity of orange juices. J. Food Compos Anal., 20: 313-22

Kumar, P., singh, S. K. and Singh, B. (2009). Standardization of methodology for the preparation of beverages and studies during preparation. Progressive Agric., 9(1): 98-103

Liu, F., Wang, Y., Li, R., Bi, X. and Liao X. (2014). Effects of high hydrostatic pressure and high temperature short time on antioxidant activity, antioxidant compounds and color of mango nectars. Inn. Food Sci. Emer. Technol., 21:35-43

Mgaya-Kilima, B., Remberg, S. F., Chove B. E. and Wicklund, T. (2014). Influence of storage temperature and time on the physicochemical and bioactive properties of roselle-fruit juice blends in plastic bottle. Food Sci. Nutr., 2(2): 181-191

Negi, P. S. and Roy, K. (2000). Effect of blanching and drying method on carotene, ascorbic acid and chlorophyll retention of leafy vegetable. LWT-Food Sci. Technol., 33(4): 295-298

Prior, R. L. and Cao, G. (2000). Antioxidant phytochemicals in fruits and vegetables. Diet and health implications. Hort. Sci., 35(4): 588-592

Priyanka, N., Dorajeerao, A. V. D. and Sudhavani, V. (2015) Utilisation of jamun juice by making blended RTS beverages. Plant Arch., 15(2): 1083-1088

Ranganna, S. (1986). Handbook of analysis and quality control for fruit and egetable product. Tata McGraw Hill Pub Co. Ltd., New Delhi, India.

Saci, F., Meziant, L. and Louaileche, H. (2015). Effect of storage time and temperature on the health-promoting substances and antioxidant activity of two commercial fruit based-beverages. International Journal of Bioinformatics and Biomedical Engineering, 1(2):118-122

Samec, D., Piljac-Zegarac, J. and Bogovi, M. (2011). Antioxidant potency of white (Brassica oleracea L. var. capitata) and Chinese (Brassica rapa L. var. pekinensis (Lour.)) cabbage: The influence of development stage, cultivar choice and seed selection. Sci Hort., 128(2):78-83

Singleton, V. L. and Rossi, J. A. (1965). Colorimetry of total phenolics with phosphomolybdic-phosphotungstic acid reagents. Amer. J. Enol Viticult., 16: 144-153

Tang, L., Zirpoli, G. R. and Guru, K. (2007). Consumption of raw cruciferous vegetables is inversely associated with bladder. Cancer Risk., 67(8):3569-73

Vallverdu-Queralt, A., Arranz, S., Medina-Remon, A., Casals-Ribes, I. and Lamuela- Raventos, R. M. (2011). Changes in phenolic content of tomato products during storage. J. Agric. Food Chem., 59(17): 9359-9365 